\title{
Cholera, Iron and Mental Illness in Nineteenth-Century Saint John, NB
}

\section{Paul TE Cusacki*}

Brealey Drive, Peterborough, 77432, Infrobright, Canada

\begin{abstract}
Saint John has a very high rate of Sz in its mainly Irish population. In this paper I examine the possible cause of iron from cast iron piping along with iron in the diet that lead to a weakened immune system and consequent contagious disease such as Cholera. Cholera may do damage to the DNA of fertile women who pass it on to their offspring.
\end{abstract}

Keywords: Cholera; Water supply; Iron; Schizophrenia; Nervous system illnesses

\section{Introduction}

Saint John, NB has double the rate of Schizophrenia compared to the rest of Canada. Its rate is $2.0 \%$. In Canada as a whole, the rate is $1.0 \%$. I will investigate the probable cause for this remarkable abdominally $[1,2]$.

\section{Cholera epidemic Saint John}

There was a Cholera epidemic in Saint John and Portland (North End) in the summer of 1854, but a much smaller one in 1834. Read about it here from Bilson [3].

In 1854, Saint John suffered one of the worst attacks of Cholera in Canadian history. Twenty years before, fifty people had died of the disease, but that had been long forgotten and the disease returned with all the force of novelty.1. In the new epidemic, at least one thousand people died and contemporaries estimated that 1,500 of the city's 30,000 residents were killed.

The Courier, 15 November 1834. In 1854, Saint John newspapers frequently referred to the Halifax epidemic of 1834, rarely to the Saint John epidemic. 2 Nearly 1,000 victims are listed in the "Records of deaths by Cholera in the City of Saint John and Parish of Portland," Mayor's Office. City Hall, Saint John.

Cholera is a contagious disease which affects those with weakens immune systems. According to Bilson,

In 1854 Dr. John Snow demonstrated that an outbreak of Cholera in one district of London could be connected with the water supply from a particular pump and confirmed that Cholera was contagious and that water fouled by the waste of Cholera patients played an important part in the spread of the disease.

The Crimean War raged in Europe as Cholera swept around the world which was believed to have started in India.

Life was difficult that year. Preparations for war in Europe had created a demand for supplies that pushed prices in New Brunswick to record heights.

Cholera was introduced by the Brig Blanche from Liverpool by a German immigrant who moved to the South end Peninsula of the heart of Saint John. The living conditions were poor and overcrowded and unsanitary.

Cholera reached Saint John on board the ship Blanche, from Liverpool, in mid-April. Amongst the passengers were a number of German immigrants who were described as being in a filthy state on their arrival. There had been deaths during the voyage and the passengers were required to go ashore at the quarantine station on Partridge Island. On 20 April, the lieutenant governor was told that Cholera existed on the island and he ordered the staff there and the mayor of Saint John to take the necessary precautions.

Saint John, like many places around the globe, suffered a severe Cholera attack in 1854 that infected 5000 and killed 1100 out of a population of 30,000 .

So, what leads to Cholera? A weakened immune system could lead to the contagion. We will consider the water and diet. Saint John is heavily populated by the/Irish. There are few minorities besides those from the UK, Lebanon, and Jewish backgrounds.

\section{The Provincial Lunatic Asylum Saint John and Cholera 1854}

The Provincial Lunatic Asylum located in Saint John, published an Annual Report. Unusually, they published a list of the patients' names in their 1870-75 editions. Table 1 below summarizes tat data.

The average rate of new admissions is $(68+32) / 5$ years $=100 / 5=20$ New patience per year. They are $68 \%$ male and $32 \%$ female .The population of Saint John was approximately 30,000 .

So $20 / 30,000=0.0667 \%$ of the total population is admitted from Saint John to the Provincial Lunatic Asylum over 5 years from 1870-75 (Table 2).

So, from these data, we see the ratio of the probability of having Mental illness with Cholera in the surname, for males and females.

For males: $43 / 93=46.24 \%$

For females: $30 / 65=46.15 \%$

Average rate for male and females: $46.195 \%$

We conclude that there is an essentially equal probability for both male and females of having mental illness with Cholera in the family surname.

Is this different from the expected mean? The expected rate is $0.3 \%$ (90 beds/30,000 pop.) chance of having mental illness and $1100 / 30,000=3.667 \%$ chance of dying from Cholera.

*Corresponding author: Cusack P, Brealey Drive, Peterborough, 77432 Infrobright, Canada, Tel: (506) 214-331; E-mail: St-michael@hotmail.com

Received March 02, 2017; Accepted April 20, 2017; Published April 25, 2017

Citation: Cusacki PTE (2017) Cholera, Iron and Mental IIIness in NineteenthCentury Saint John, NB. J Biom Biostat 8: 341. doi:10.4172/2155-6180.1000341

Copyright: ( 92017 Cusacki PTE. This is an open-access article distributed under the terms of the Creative Commons Attribution License, which permits unrestricted use, distribution, and reproduction in any medium, provided the original author and source are credited. 
Citation: Cusacki PTE (2017) Cholera, Iron and Mental Illness in Nineteenth-Century Saint John, NB. J Biom Biostat 8: 341. doi:10.4172/21556180.1000341

Page 2 of 4

\begin{tabular}{|c|c|c|c|c|c|c|c|}
\hline Year & Number & Male & Remaining & Discharge/Death & Female & Remaining & Discharge/Death \\
\hline 1870 & 14 & 11 & 5 & 11 & 3 & 3 & 3 \\
\hline 1871 & 29 & 19 & 6 & 14 & 10 & 6 & 7 \\
\hline 1872 & 30 & 17 & 6 & 11 & 13 & 5 & 7 \\
\hline 1873 & 25 & 12 & 4 & 16 & 13 & 6 & 8 \\
\hline 1874 & 26 & 16 & 4 & 12 & 10 & 5 & 4 \\
\hline 1875 & 34 & 18 & 9 & 14 & 16 & 7 & 11 \\
\hline SUM & 158 & 93 & 34 & 68 & 65 & 32 & 40 \\
\hline
\end{tabular}

Table 1: Provincial lunatic asylum annual report 1870-75 surnames data

\begin{tabular}{|c|c|c|c|}
\hline Year & $\begin{array}{c}\text { Total Number of surnames w/Cholera } \\
\mathbf{1 8 5 4}\end{array}$ & $\begin{array}{c}\text { Number of males surnames w/Cholera } \\
\mathbf{1 8 5 4}\end{array}$ & $\begin{array}{c}\text { Number of female surnames w/ } \\
\text { Cholera 1854 }\end{array}$ \\
\hline 1870 & 7 & 0 \\
\hline 1871 & 18 & 14 \\
\hline 1872 & 13 & 5 & 5 \\
\hline 1873 & 11 & 5 \\
\hline 1874 & 11 & 6 \\
\hline 1875 & 16 & 9 \\
\hline SUM & 76 & 43 \\
\hline
\end{tabular}

Table 2: Saint John and Portland cholera deaths 1854 surname data summary.

$\operatorname{Pr}[\mathrm{A} / \mathrm{B}]=\operatorname{Pr}[\mathrm{B} \cap \mathrm{A}] / \operatorname{Pr}[\mathrm{B}]$

$\operatorname{Pr}[\mathrm{A} / \mathrm{B}]=76 / 158=48.1 \%$

$\mu_{0}=0.3 \%$

$\mu_{1}=16.67 \% \times 48.1 \%=34.6 \%$

$\mu_{1} / \mu_{0}=34.6 / 0.3=115.5 \mathrm{X}$ 's

$0.3 / 34.6=0.866=\sin 60^{\circ}=$ Superforce

$\operatorname{Pr}[\mathrm{B} / \mathrm{A}]=\operatorname{Pr}[\mathrm{A}$ and $\mathrm{B}] / \operatorname{Pr}[\mathrm{A}]$

$=\operatorname{Pr}[\mathrm{A}] \times \operatorname{Pr}[\mathrm{B}] /[\mathrm{B} / \mathrm{A}]$

$=3.667 \% \times[46.195 \% / 0.3 \%]$

$=564.65 \% \sim 1 /$ Sqrt Pi

$=$ Probability of Mental illness given Cholera

Now, Cusack's Laws of Contagion:

Golden Mean:

$\mathrm{x}^{2}-\mathrm{x}-1=0=\mathrm{E}$

$(1 / \sqrt{ } \pi)^{2}-(1 / \sqrt{ } \pi)-1=\mathrm{E}$

$\mathrm{E}=1 / 81=1 / \mathrm{c}^{4}=1.2345679$

But $\mathrm{E}=\mathrm{Mc}^{2}$

$1 / \mathrm{c}^{4}=\mathrm{Mc}^{2}$

$M=1 / c^{\wedge}{ }^{6}$

$=0.001372$

$1-0.1372=0.863=\sin 60^{\circ}=1.04 \mathrm{rads}$

$1.04 \times 2 \pi=6.53=\mathrm{G}=\pi / \operatorname{Ln} 1.618$

Since the general population has a probability of having mental illness without Cholera is $0.3 \%$ and the probability of having Cholera in the surname is $34.6 \%$, I won't do a Null Hypothesis test. The answer is, yes, obviously there is a significant difference in the means.

Thus, if you have Cholera in your family, there may be a $160 \mathrm{X}$ 's increase risk of developing mental illness.
So there were about 5000 people who had Cholera Saint John out of population of 30,000 . or $1 / 6$.

Consider that the population of Saint John is 127,000 .

$1 / 6 \times 127,000=21,167$ with mental illness.

This accounts for $16.7 \%$ of the population with mental illness serious enough to be hospitalized.

Cf $20 \%$ of Canadians suffers with mental illness. The other $3.3 \%$ is:

$\operatorname{Pr}[\mathrm{A}$ and $\mathrm{B}]=[\operatorname{Pr}[\mathrm{B} / \mathrm{A}] \times \operatorname{Pr}[\mathrm{A}]$,

$=\operatorname{Pr}\{$ Dying from Cholera $\mathrm{w} /$ mental illness $] \times \operatorname{Pr}[$ Mental illness]

$=3.66 \% \times 0.3$

$=1.1 \%$

$=\operatorname{Pr}[$ Dying from Cholera and having mental illness].

Cf. $(68+32) / 1103=0.299 \sim 3.0 \%$ (Table 1$)$.

$16.7 \%+1.1 \%=17.8 \%$

$=1 /$ sqrt Pi

$=\operatorname{Sqrt}(\mathrm{T})=\operatorname{Sqrt}(\mathrm{E})$.

\section{The Saint John water supply}

The Water Supply in Saint John came from wells up until 1838 whence it came from Lily Lake now in Rockwood Park.

The Saint John and Portland Water supply was serviced by three water iron water reservoirs.

- $\quad$ Leinster St Reservoir (1836); South End

- $\quad$ Little River (1850); Portland or North End

- Lake Latimer (1851); East Side.

One was installed in 1851 (pre Cholera epidemic). There was 69,325 feet of cast iron piping in the two towns with a capacity of 350,000 imperial gallons per day.

The Lunatic Asylum was started in 1838 on Leinster Street. It was 
Citation: Cusacki PTE (2017) Cholera, Iron and Mental Illness in Nineteenth-Century Saint John, NB. J Biom Biostat 8: 341. doi:10.4172/21556180.1000341

converted from the hospital used for the Cholera in 1834 (50 deaths The Courier, 15 November 1834).

From 1838 to 1854 is 16 years. This is the time a woman is fertile. The grand children should appear in about 1870-75. (There are published sources of surnames in the Annual Report of the Provincial Lunatic Asylum for this period. Access is difficult if not impossible due to privacy). Her DNA and offspring could be affected by the Cholera attacks.

In 1834, pre Lily Lake Iron Overload, there were only 50 Cholera deaths. In 1854, post Lily Lake water supply, there were 1100 Cholera deaths and 5000 cases. There would not have been too much change in the way people lived in those intervening years [4]. Perhaps the iron in the water overloads the body and the immune system is weakened allowing infectious Cholera to furbish. Mental infirmity results due to damage done to the DNA of the mothers and grandmothers of the mentally infirm.

\section{Iron overload}

Too much iron weakens the immune system-insufficient $\mathrm{T}$ cells [59]. The Irish eat a lot of potatoes which are high in iron. The drinking water from Lily Lake-the city's supply has a lot of iron. The water system from that lake wasn't installed until 1838 (Figures 1 and 2). The

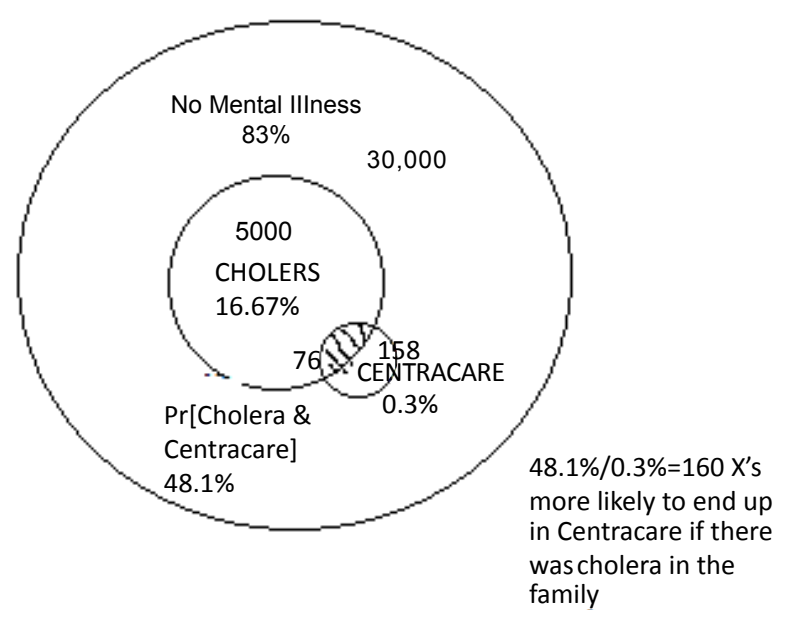

Figure 1: Intersection probability. first Cholera was 1834 . Only 50 people died. The second Cholera, after the Lily Lake water, had 1100 people die.

\section{Some ad hoc cases of nervous system infirmities of Prince Edward Ward and defendants}

Donald (Schizoid), Bill (Schizoid, Alz) 1, BJ (eye cancer), and Pau (Sz)l all had nervous diseases. Edward, off Richmond Street, had an eye disease. Their Iron was too high supressing their immune system and allowing Cholera to flourish. Cholera damages the DNA. (So does LSD.) Maggie had Cholera after the birth of Margaret on Erin StreePrince Edward Ward.t. Seaton Street, where the family lived as well, might have used Lily Lake water.

\section{The Irish of Prince Edward Ward}

- Ed (lazy eye) Richmond Street

- Wm. (SchozoidAlz)Erin Street; Wm Jr Cusack (Eye cancer)

- Don (Schoizoid) Erin Street; Paul (Sz).

Other antidotal cases w/Cholera

- Anderson; M. (Sz); Anderson J. (Sz)

- Higgins (Sz)

- Power (Mentally Retarded)

- Reed - Mental retardation)

The Lebanese do not eat potatoes high in iron. They don't have mental illness despite living in the same neighbourhood, Prince Edward Ward.

\section{The Lebanese of Prince Edward Ward}

Sound mental health. Peter (Speech Impediment). The rest of the Saint John Lebanese have no mental health infirmities. They are accomplished, lawyers, doctors, teachers, business men and priests. They are well educated as a general observation as a group.

Saint John's first water supply came from Lily Lake in 1838 after many previous unsuccessful attempts, carried by a flume of wood to a pumping station at the foot of Brussel Street. Saint John Firsts

Prince Edward Ward Streets: Brussel St, now Prince Edward St.; St Patrick; St David; Erin St; Albion St; Richmond St; Brunswick St Clarence St; Courtenay St. Hanover St; Exmouth St; Waterloo.

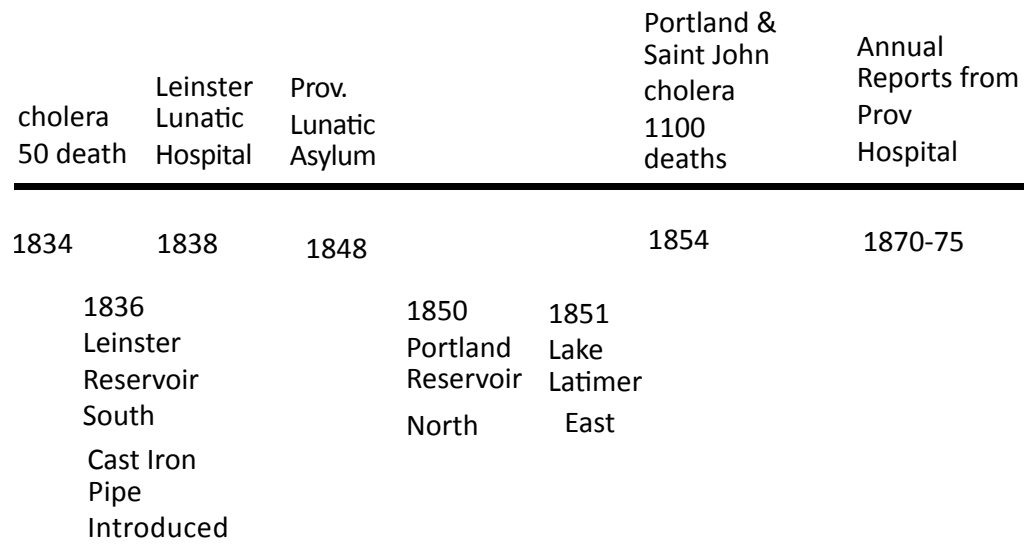

Figure 2: Timeline of cast iron pipe installation servicing various areas of the city and Cholera epidemics. 
Citation: Cusacki PTE (2017) Cholera, Iron and Mental Illness in Nineteenth-Century Saint John, NB. J Biom Biostat 8: 341. doi:10.4172/21556180.1000341

Cf Saint John and Portland Cholera Deaths 1854. Street Locations.

The Irish eat a lot off potatoes which are high in iron; the Lebanese do not. The Irish have nervous system and eye diseases; the Lebanese do not. Their environments were the same since they lived in the same ward on the same streets.

Increased body stores of iron in various clinical situations may tip the immunoregulatory balance unfavorably to allow increased growth rates of cancer cells and infectious organisms [Cholera], and complicate the clinical management of pre-existing acute and chronic diseases...........in iron-overloaded patients. Iron overload as seen in hereditary hemochromatosis patients enhances suppressor T-cell (CD8) numbers and activity, decreases the proliferative capacity, numbers, and activity of helper T cells [5]

\section{Caffeine}

Caffeine affect negatively calcium uptake. We should see weak teeth in those who consume caffeine such as the Irish who traditionally drink a lot of tea.

Tea, coffee, cola and chocolate all contain caffeine, which acts as a stimulant and can interfere with the absorption of certain nutrients when you get large amounts in your diet. People with iron deficiencies are often advised to avoid caffeine due to its potential to reduce iron absorption.

http://www.livestrong.com/article/427404-caffeines-effect-oniron-absorption

There was the need for three other hospitals in Saint John in the 20th Century, including the old General (c 1880); The TB Hospital (c 1930); and the General Hospital (c.1935) as well as the Provincial Lunatic Asylums (1838 \& 1848).

\section{Conclusion}

In this paper, we considered that there may be a link between iron in the diet and in the drinking water. It causes the immune system to be supressed allowing disease such as Cholera (or cancer) to flourish. If an individual has Cholera in their family surname, there is a 160 times more likely hood of having serious mental illness in succeeding generations to the third generation. The Cholera damages the DNA of fertile women leading to mental illness and other nervous system infirmities. Hyperferremia should be studied to see what acceptable levels to prevent such illness and diseases are. Cast Iron pipping in the old water systems should be replaced as well as iron piping in housing.

\section{References}

1. Somerville GF (1854) Saint John and Portland cholera Deaths. Saint John, NB

2. Bilson G (1980) A Darkened House, Cholera in 19th Century Canada University of Toronto Press.

3. Bislon G (1854) The Cholera Epidemic in Saint John, NB, Acadiensis.

4. Weiss NA (2008) Introductory Statistics. (8thedn), Pearson, Addison Wesley, USA.

5. Walker EM, Walker SM (2000) Effects of iron overload on the immune system.

6. Murdoch G (1857) Special Report on the Water Supply for Saint John and Portland, Engineering Department, Sewerage and Water Works, J \& A McMillan Saint john NB, 188.

7. Cusack $P(2015)$ Sz and its cause, LULU.

8. Cholera and Mental Illness (2017) Mental health, Family Medicine.

9. Annual Reports of the Provincial Lunatic Asylum. New Brunswick, 1870-1875. 